\title{
PREFERENSI EKS NASABAH BMT PAILIT TERHADAP MINAT MENABUNG PADA BMT (STUDI KECAMATAN CIAWI)
}

\section{PREFERENCE EX CUSTOMERS OF BMT BANKRUPTCY TOWARD SAVING UP INTEREST IN BMT (STUDY CIAWI DISTRICT)}

\author{
R. Sari' ${ }^{1}$ M. Paramita 2 , M. Komarudin ${ }^{3}$ \\ 1aProgram Studi Ekonomi Syariah Fakultas Ekonomi Islam Universitas Djuanda, Jl. Tol Ciawi No. 1, \\ Kotak Pos 35 Bogor 16720 \\ 2Program Studi Ekonomi Syariah Fakultas Ekonomi Islam Universitas Djuanda, Jl. Tol Ciawi No. 1, \\ Kotak Pos 35 Bogor 16720 \\ 3Program Studi Perbankan Syariah Fakultas Ekonomi Islam Universitas Djuanda, Jl. Tol Ciawi No. 1, \\ Kotak Pos 35 Bogor 16720
}

\begin{abstract}
The purpose of this study is to determine the interest of saving ex customers BMT bankruptcy. The method used is quantitative method, by using data collection techniques of questionnaires spread to ex bankrupt BMT customers in Ciawi sub-district. The number of respondents in this study as many as 30 ex-customers BMT bankruptcy. Data analysis used in this research is chi-square analysis. The results of this study indicate that based on the results of analysis conducted pre-customer preferences seen from the aspect of sharia, the level of trust and experience have no interest in saving in BMT after a bankruptcy.
\end{abstract}

Key words: Ex Customer, BMT Bankruptcy, Interest in Saving

\begin{abstract}
ABSTRAK
Tujuan penelitian ini adalah untuk mengetahui minat menabung eks nasabah BMT pailit. Metode yang digunakan yaitu metode kuantitatif, dengan menggunakan teknik pengumpulan data penyebaran kuesioner kepada eks nasabah BMT pailit di kecamatan Ciawi. Jumlah responden pada penelitian ini sebanyak 30 orang eks nasabah BMT pailit. Teknik analisis data yang digunakan dalam penelitian ini yaitu analisis chi-square. Hasil penelitian ini menunjukkan bahwa berdasarkan hasil analisis yang dilakukan preferensi eks nasabah dilihat dari aspek syariah tingkat kepercayaan dan pengalaman tidak mempengaruhi minat menabung di BMT setelah pailit.
\end{abstract}

Kata kunci: Eks Nasabah, BMT Pailit, Minat Menabung

Ratna Sari. 2018. Preferensi Eks Nasabah BMT Pailit terhadap Minat Menabung pada BMT (Studi Kecamatan Ciawi). Jurnal Syarikah 5 (1): 73-82.

\section{PENDAHULUAN}

Perkembangan Baitul Maal Wat Tamwil (BMT) di masyarakat terus mengalami peningkatan, hal ini ditandai dengan banyak didirikannya BMT di berbagai wilayah. Berdasarkan data
Otoritas Jasa Keuangan (OJK), di Indonesia total LKMS/BMT pada tahun 2015 mencapai 4.500 LKMS/BMT (OJK, 2015). Data tersebut menunjukkan terjadinya peningkatan jumlah LKMS/BMT yang ada di Indonesia. 
Seiring dengan perkembangan BMT yang terus mengalami peningkatan, persepsi masyarakat terhadap BMT juga mengalami perubahan dari waktu ke waktu. Perubahan tersebut dapat dipengaruhi oleh beberapa faktor yaitu kualitas pelayanan yang diberikan BMT kepada nasabah, kepuasan nasabah dalam menggunakan produk dan jasa BMT, serta tingkat kepercayaan nasabah terhadap produk dan jasa BMT (Guspul \& Ahmad, 2014: 157).

Kepercayaan nasabah terhadap BMT dapat berubah salah satunya dikarenakan BMT mengalami pailit. Berdasarkan fakta lapangan terdapat beberapa BMT yang mengalami pailit, seperti yang terjadi di daerah Sleman Yogyakarta terdapat sekitar 17 BMT yang mengalami pailit. Hal ini disebabkan karena masalah likuiditas, macetnya dana pinjaman bergulir di masyarakat (Suaidi, 2014: 7). BMT yang mengalami pailit akan menimbulkan kerugian, baik bagi BMT itu sendiri maupun bagi nasabahnya. Kerugian yang akan dialami oleh BMT yaitu tidak mampu melunasi kewajibannya terhadap bank karena jumlah kredit macet yang besar dan tidak tertagih (Sukmana, 2016: 126).

BMT yang mengalami pailit tidak hanya akan mengalami kerugian secara materi namun juga non materi. Kerugian non materi yang akan BMT rasakan yaitu tingkat kepercayaan nasabah terhadap BMT akan berkurang bahkan mungkin menjadi tidak percaya lagi. Kemudian, image BMT di masyarakat akan menurun sehingga banyak nasabah yang beralih menggunakan produk dan jasa dari lembaga keuangan lain.

Dampak terbesar dari BMT yang mengalami pailit akan dirasakan oleh nasabahnya, karena nasabah merupakan pihak yang banyak mengalami kerugian.

\section{MATERI DAN METODE}

Preferensi berasal dari kata prefer yang artinya kesukaan atau kecenderungan seseorang dalam melakukan pilihan. Menurut Bilson Simamora (2004) dalam (Sofhian, 2016: 100) preferensi konsumen dapat diukur melalui tingkat kegunaan pada setiap produk barang dan jasa. Penilaian terhadap produk dan jasa akan menggambarkan sikap konsumen tersebut, sehingga tercermin preferensi konsumen.

Preferensi dalam Islam, dimana seseorang menggunakan kekayaan harus secara berhati-hati, yang paling terpenting adalah penggunaan harta yang diarahkan berdasarkan pilihan-pilihan (preferensi) yang tentunya harus baik dan bermanfaat (maslahah). Hal ini bertujuan agar harta tersebut dapat memberikan manfaat dan kesejahteraan bagi individu tersebut (Syawalia, 2015: 4).

Preferensi memiliki beberapa indikator yaitu aspek syariah, tingkat kepercayaan dan Pengalaman. Aspek syariah terdiri dari beberapa hal yaitu penghapusan dan pelarangan riba (prohibitation of riba) tetapi mejadikan sistem bagi hasil (profit loss sharing) sebagai penggantinya dengan menggunakan instrumen kerjasama seperti mudharabah dan musyarakah dibandingkan menggunakan bunga, menjalankan usaha halal (pemissible conduct) baik dari produk atau komoditas, manajemen, proses produksi hingga distribusi harus jelas kehalalannya. Usaha yang dilakukan dilarang bersentuhan dengan judi (maisir) dan spekulasi (gharar) (Kurniati, 2012: 261). Aspek syariah merupakan penilaian penting bagi nasabah, karena salah satu faktor yang mempengaruhi nasabah memilih lembaga keuangan syariah adalah kehalalan produk dan transaksi yang dilakukan. Aspek syariah juga dapat dilihat dari kebijakan-kebijakan yang dijalankan oleh lembaga keuangan syariah yang dalam kegiatan operasionalnya tidak melanggar syariat agama (Dewi \& Satria, 2014: 39).

Tingkat kepercayaan merupakan keyakinan bahwa seseorang akan menemukan apa yang diinginkan dan dibutuhkan pada orang lain. Kepercayaan melibatkan seseorang untuk bertingkah laku tertentu hal ini disebabkan karena keyakinan akan memberikan kepuasan terhadap yang diharapkan. Kepercayaan 
terdiri dari 3 kompenen yaitu integritas (integrity), kebaikan (benevolence) dan kompetensi (competence).

Menurut Prastaningsih et al 2014 dalam (Astarina, Giantari., dkk. 2017: 2313) pengalaman konsumen dalam penggunaan produk dan jasa akan membentuk suatu penilaian terhadap produk dan jasa tersebut seperti pelayanan, kemudahan akses, dan sebagainya. Pengalaman merupakan salah satu yang penting bagi konsumen. Penggunaan produk dan jasa konsumen tidak hanya sekedar mengkonsumsi produk dan jasa tersebut, tetapi dibutuhkan pengalaman yang berkesan dalam kegiatan konsumsi tersebut.

Preferensi eks nasabah dapat dikaitkan dengan teori pascapembelian, Menurut U.Sumarwan 2011 dalam Suntoyo (2013: 135) proses pengambilan keputusan, konsumen tidak akan berhenti hanya sampai pada tahap konsumsi, tetapi konsumen akan melakukan evaluasi terhadap produk dan jasa yang dikonsumsi. Evaluasi inilah yang disebut dengan evaluasi alternatif pascapembelian. Berdasarkan proses evaluasi, konsumen akan merasa puas atau tidak puas terhadap konsumsi produk dan jasa yang dilakukannya. Kepuasan yang dirasakan oleh konsumen mendorong untuk melakukan konsumsi ulang produk dan jasa tersebut. Sebaliknya, perasaan tidak puas menyebabkan konsumen mengalami kekecewaan sehingga akan menghentikan penggunaan produk dan jasa tersebut.

Seseorang memutuskan pembelian suatu barang dan jasa berdasarkan dua kepentingan yaitu keputusan berdasarkan ketersediaan dan penggunaan suatu produk, konsumen akan memutuskan melakukan pembelian suatu produk jika produk yang ditawarkan bermanfaat bagi dirinya dan keputusan berdasarkan hubungan dari produk atau jasa, konsumen akan memutuskan membeli suatu produk apabila memiliki hubungan yang diinginkan oleh konsumen. Terdapat beberapa proses keputusan pembelian yaitu input proses dan output. Input terdiri dari faktor eksternal dengan bentuk informasi mengenai produk, mempengaruhi nilai serta sikap perilaku konsumen. Proses dalam pengambilan keputusan terdiri dari mengenali kebutuhan konsumen, mencari informasi sebelum melakukan pembelian dan evaluasi alternatif. Sedangkan ouput model keputusan pembelian konsumen melalui pendekatan perilaku pembelian (pembelian coba-coba, pembelian berulangulang) dan evaluasi setelah pembelian.

Tingkat analisa setelah melakukan pembelian tergantung pentingnya kebutuhan suatu produk dan pengalaman menggunakan produk. Apabila produk mengecewakan, otomatis konsumen akan mencari alternatif lain yang sesuai dengan keinginannya. Evaluasi setelah pembelian merupakan feedback dapat berupa pengalaman konsumen dan akan mempengaruhi keputusan pembelian (Schiffman \& Kanuk, 2007).

\section{Jenis Penelitian}

Jenis penelitian yang digunakan dalam karya ilmiah ini yaitu kuantitatif dengan tujuan untuk mengetahui minat menabung eks nasabah BMT pailit di kecamatan Ciawi.

\section{Populasi dan Sampel}

Populasi merupakan wilayah generalisasi yang terdiri atas obyek atau subyek yang mempunyai kualitas dan karakteristik tertentu yang diterapkan oleh peneliti untuk dipelajari dan kemudian ditarik kesimpulannya (Sugiyono, 2015: 80). Populasi dalam penelitian ini yaitu seluruh nasabah BMT pailit di Kecamatan Ciawi yang jumlahnya tidak diketahui. Penentuan sampel dalam studi ini yaitu eks nasabah BMT pailit di kecamatan Ciawi dengan jumlah 30 responden.

\section{Teknik Sampling}

Sampel merupakan bagian dari jumlah dan karakteristik yang dimiliki oleh populasi tersebut (Sugiyono, 2015: 80). Teknik pengambilan sampel yang digunakan dalam penelitian ini yaitu purposive sampling, dimana teknik pengambilan sampel berdasarkan kepada pertimbangan dan kriteria tertentu seperti 
responden merupakan eks nasabah BMT pailit di kecamatan Ciawi dan responden mudah ditemui dan bersedia mengisi kuesioner yang diberikan.

Pengambilan sampel dalam penelitian ini diambil berdasarkan kebutuhannya dengan syarat 30 orang atau lebih eks nasabah BMT pailit. Penelitian ini mengambil sampel sebanyak 30 orang, hal ini disebabkan karena tidak diketahui jumlah seluruh eks nasabah yang mengalami kerugian dari BMT pailit di Kecamatan Ciawi.

\section{Sumber Data}

Sumber data berasal dari berbagai bentuk seperti dokumen-dokumen, wawancara, kuesioner dan sebagainya. Secara umum. jenis data terbagi menjadi dua macam yaitu data primer dan data sekunder:

1. Data Primer, berupa data pokok yang menjadi sumber utama dalam penelitian yang dilakukan melalui wawancara, kuesioner, observasi dan alat-alat lainnya yang dapat digunakan (Arikunto, 2010: 145). Data primer yang digunakan dalam penelitian ini diperoleh berdasarkan hasil wawancara dan penyebaran kuesioner kepada eks nasabah BMT pailit di Kecamatan Ciawi.

2. Data Sekunder, data yang digunakan sebagai data pendukung dan penunjang dalam penelitian (Arikunto, 2010: 157). Data sekunder bukan berasal dari sumber langsung namun dari sumber lain seperti buku, jurnal, karya ilmiah, internet, dan bahan pustaka lainnya yang berkaitan dengan penelitian yang akan dilakukan.

\section{Teknik Pengumpulan Data}

Cara mengumpulkan data dilaksanakan melalui wawancara dan pembagian kuesioner kepada responden.

1. Wawancara, teknik wawancara digunakan ketika peneliti ingin mengetahui lebih dalam mengenai suatu hal. Teknik pengumpulan data ini bedasarkan pada laporan mengenai diri sendiri (self report) atau pengetahuan dan keyakinan peribadi (Sugiyono, 2010). Wawancara yang digunakan dalam penelitian ini adalah wawancara semi terstruktur, dimana peneliti sudah menyiapkan daftar pertanyaan namun tidak menjadi acuan utama dalam melakukan wawancara.

2. Kuesioner, Kuesioner berisi kumpulan daftar pertanyaan yang harus dipelajari dan dijawab oleh responden. Tujuan kuesioner untuk mengetahui tanggapan responden terhadap pertanyaan yang diajukan. Kuesioner dalam penelitian ini disebarkan kepada 30 responden eks nasabah BMT pailit. Kuesioner yang digunakan menggunakan skala likert. Skala likert berisi kumpulan-kumpulan pertanyaan sikap yang disusun dan dianalisis sehingga respon seseorang terhadap pertanyaan tersebut dapat diberikan penilaian berupa angka (skor) dan kemudian dapat dipresentasikan. Skor yang dapat digunakan dalam skala likert yaitu Sangat Setuju (SS), Setuju (S), Kurang Setuju (KS), Tidak Setuju (TS) dan Sangat Tidak Setuju (STS).

\section{Teknik Analisis Data}

Penelitian ini menggunakan teknik melalui tahap-tahap sebagai berikut:

1. Uji Validitas dan Uji Validitas

Uji validitas merupakan derajat ketepatan antara data pada objek dengan data yang diperoleh dilapangan oleh peneliti (Sugiyono, 2015: 267). Instrumen yang valid menunjukkan bahwa alat ukur yang digunakan untuk memperoleh data itu valid. Uji validitas ini mengukur valid tidaknya suatu kuesioner yang digunakan dalam penelitian ini.

Uji reliabilitas dilakukan apabila suatu alat ukur telah dinyatakan valid, maka tahap selanjurnya yaitu mengukur reliabilitas dari alat. Uji reliabilitas merupakan alat untuk mengukur instumen penelitian yang menjadi indikator dari varibel. Uji reliabilitas ini 
mengukur konsisten dan stabilitas suatu skor dalam alat analisis yang digunakan.

2. Analisis Data

Teknik analisis data yang digunakan dalam penelitian ini yaitu teknik analisis Chi Square. Analisis Chi Square merupakan salah satu teknik analisis data dimana tentang perbandingan antara observasi dengan frekuensi harapan berdasarkan pada hipotesis tertentu pada suatu fenomena yang diamati. Analisis ini sangat bermanfaat untuk melakukan analisis statistik namun tidak memiliki informasi mengenai populasi atau apabila asumsiasumsi yang disyaratkan untuk penggunaan statistik tidak terpenuhi. Biasanya Chi kuadrat dalam frekuensi observasi dilambangkan dengan frekuensi harapan yang bergantung pada satu parameter yaitu derajat kebebasan (df).

\section{HASIL DAN PEMBAHASAN}

\section{Karakteristik Responden}

Karakteristik ressponden dalam penelitiam ini meliputi 5 variabel yaitu jenis kelamin yang terbagi menjadi dua kategori yaitu laki-laki dan perempuan, usia yang dibedakan menjadi 6 kategori dengan perbedaan range usia 10 tahun atau satu dekade, pendidikan terakhir, pekerjaan dam julah simpanan serta lama menjadi nasabah.

\section{Tabel 1. Karakteristik Responden}

\begin{tabular}{|l|l|l|}
\hline \multicolumn{1}{|c|}{ Karakteristik } & \multicolumn{1}{|c|}{ Uraian } & Jumlah \\
\hline Jenis Kelamin & Laki-laki & 10 \\
& Perempuan & 20 \\
\hline Usia & $<20$ & 1 \\
& $21-30$ & 8 \\
& $31-40$ & 10 \\
& $41-50$ & 8 \\
& $>50$ & 3 \\
\hline Pendidikan terakhir & SD & 2 \\
& SMP & 4 \\
& SMA & 15 \\
& Diploma & 1 \\
& Sarjana & 6 \\
\hline Pekerjaan & Pelajar/ & 3 \\
& Mahasiswa & \\
& Pegawai & 14 \\
& Swasta & \\
\hline
\end{tabular}

\begin{tabular}{|l|l|l|}
\hline & Wiraswasta & 13 \\
\hline Jumlah simpanan & $<1$ juta & 5 \\
& $1-5$ juta & 9 \\
& $5-10$ juta & 4 \\
$10-15$ juta & 8 \\
& $15-20$ juta & 1 \\
& $>20$ juta & 3 \\
\hline Lama menjadi & $<1$ tahun & 3 \\
nasabah & $1-5$ tahun & 15 \\
& $5-10$ & 8 \\
& $>10$ tahun & 4 \\
\hline
\end{tabular}

Berdasarkan perolehan data diolah dari 30 responden yaitu eks nasabah BMT pailit dengan penyebaran data melalui penyebaran kuesioner, secara lebih detail responden eks nasabah BMT pailit terhadap laki-laki sebanyak 10 orang (30\%) dan perempuan 20 orang (70\%). Keadaan ini dapat dinilai bahwa mayoritas nasabah di BMT ini adalah perempuan mudah percaya terhadap produk yang ditawarkan.

Usia responden didominasi oleh usia 31-40 tahun sebanyak 10 orang (33\%), responden yang berusia 41-50 tahun sebanyak 8 orang $(27 \%)$, responden yang berusia 21-30 tahun sebanyak 8 orang (27), responden yang berusia $>50$ tahun sebanyak 3 orang (10\%) dan responden yang berusia $<20$ tahun sebanyak 1 orang (3\%). Berdasarkan data tersebut, dapat disimpulkan bahwa mayoritas nasabah di BMT ini $<20$ tahun, sehingga memiliki tingkat kedewasaan yang cukup dalam mengambil keputusan.

Responden dengan latar belakang pendidikan Sekolah Dasar (SD) berjumlah 2 orang $(7 \%)$, responden dengan latar belakang pendidikan Sekolah Menengah Pertama (SMP) berjumlah 4 orang (13\%), responden dengan latar belakang Sekolah Menengah Atas (SMA) sebanyak 15 orang (50\%), responden dengan latar belakang Diploma berjumlah 1 orang (3\%) dan responden dengan latar belakang Sarjana berjumlah 6 orang (27\%). Mayoritas responden pada BMT ini dengan pendidikan SMA sehingga memiliki pengetahuan yang cukup terhadap BMT.

Pekerjaan responden sebagai Pelajar/Mahasiswa sebanyak 3 orang 
(10\%), responden yang memiliki pekerjaan sebagai pegawai swasta sebanyak 14 orang (47\%) dan responden yang memiliki pekerjaan sebagai Wiraswasta sebanyak 13 orang (43\%). Mayoritas nasabah di BMT ini adalah pegawai swasta dan wiraswasta karena untuk memudahkan transaksi dan kegiatan usahanya.

Responden yang memiliki jumlah simpanan < Rp. 1.000 .000 sebanyak 5 orang (17\%), responden yang memiliki jumlah simpanan Rp. 1.000 .000 - Rp. 5.000 .000 sebanyak 9 orang (30\%), responden yang memiliki jumlah simpanan Rp. 5.000.001 Rp. 10.000 .000 sebanyak 4 orang (13\%), responden yang memiliki jumlah simpanan Rp. 10.000 .001 - Rp. 15.000 .000 sebanyak 8 orang (27\%), responden yang memiliki jumlah simpanan Rp. 15.000.001- Rp. 20.000.000 sebanyak 1 orang (3\%) dan responden yang memiliki jumlah simpanan > Rp. 20.000.000 sebanyak 3 orang (10\%). Berdasarkan data tersebut, dapat disimpulkan bahwa nasabah di BMT ini memiliki jumlah simpanan yang cukup banyak, sehingga sangat merugikan ketika BMT mengalami masalah.

Responden yang menjadi nasabah di BMT pailit < 1 tahun sebanyak 3 orang (10\%), responden yang menjadi nasabah di BMT pailit 1-5 tahun sebanyak 15 orang (50\%), responden yang menjadi nasabah di BMT pailit 5-10 tahun sebanyak 8 orang (27\%) dan responden yang menjadi nasabah di BMT pailit > 10 tahun sebanyak 4 orang $(13 \%)$. Mayoritas nasabah yang menabung di BMT ini adalah nasabah lama dan sudah percaya terhadap BMT.

\section{Uji Reliabilitas dan Uji Validitas}

Uji reliabilitas pada karya ilmiah ini dilakukan dengan menyebar kuesioner yang diambil dari 30 eks nasabah BMT pailit di kecamatan Ciawi. Metode yang digunakan yaitu alfa cronbach's untuk mengukur ketepatan dari indikator-indikator yang tedapat dalam penelitian. Pengambilan keputusan yang digunakan dalam penelitian ini jika alfa cronbach's $<0,60$ maka dinyatakan andal-sangat andal (putra,dkk, 2014: 178).
Berdasarkan hasil perhitungan, nilai reliabilitas sebesar 0,920 . Jika dibandingkan dengan alfa cronbach's yaitu $0,920 \geq 0,60$ yang artinya konstruk ini termasuk dalam kategori andal-sangat andal. Artinya, dapat diketahui bahwa 15 pernyataan dan pertanyaan dalam kuesioner penelitian adalah reliabel.

Tingkat validitas diketahui dari tabel Corrected Item-Total Correlation dengan memberikan petunjuk korelasi setiap item (nilai $r$ hitung) dibandingkan dengan nilai $r$ tabel. Nilai tabel menujukkan nilai 0,361. Berdasarkan hasil peroleh nilai validitas dari pernyataan nomor 1 (AS1) hingga no 15 (PL5) berada diatas 0,361. Sehingga semua pernyataan dalam kuesioner dinyatakan valid.

\section{Uji Chi-Kuadrat (Chi-Square)}

\section{Preferensi Eks Nasabah BMT Pailit Ditinjau dari Aspek Syariah}

\section{Tabel.2 Preferensi Ditinjau dari Aspek Syariah}

\begin{tabular}{lccc}
\hline & \multicolumn{3}{c}{ Chi Square } \\
\cline { 2 - 4 } Respon & Fo & Fh & $\begin{array}{c}\text { (Fo-Fh) } \\
\text { FS }\end{array}$ \\
\hline SS & 3 & 10 & 4,9 \\
S & 25 & 10 & 22,5 \\
KS & 0 & 10 & 0 \\
TS & 2 & 10 & 6,4 \\
STS & 0 & 0 & 0 \\
Total & 30 & & 33,88 \\
\hline
\end{tabular}

Berdasarkan hasil uji pada tabel 2, maka diperoleh perhitungan chi-square hitung sebesar 33,8 dengan df (degree of freedom $)=\mathrm{N}-\mathrm{k}$, dimana $\mathrm{N}$ merupakan data sampel dan $\mathrm{k}$ merupakan jumlah variabel dalam penelitian sehingga, $\mathrm{df}=30-4=26$ dengan taraf signifikansi sebesar 5\% diperoleh chi-square tabel sebesar 38,885. Kemudian, diketahui bahwa chi-square hitung lebih kecil dari chi-square tabel yaitu $33,8<38,885$ maka, $\mathrm{H}_{0}$ diterima dan $\mathrm{H}_{1}$ ditolak, artinya dilihat dari aspek syariah 
eks nasabah BMT pailit tidak memiliki minat menabung terhadap BMT lain.

Berdasarkan hasil wawancara kepada responden yaitu eks nasabah BMT pailit dilihat dari aspek syariah, eks nasabah BMT pailit menyatakan bahwa walaupun BMT sudah mengalami pailit, eks nasabah percaya dan tetap meyakini bahwa BMT sesuai syariat Islam baik produk dan jasa maupun transaksi yang dilakukan BMT. Eks nasabah juga meyakini bahwa setiap transaksi yang dilakukan oleh BMT terbebas dari sistem bunga yang merugikan nasabah. Namun, hal tersebut tidak cukup kuat untuk menumbuhkan minat menabung eks nasabah di BMT setelah mengalami pailit. Hal ini disebabkan eks nasabah merupakan pihak yang paling dirugikan dari BMT yang mengalami pailit, baik kerugian dari segi materi dan kerugian non materi seperti kekecewaan terhadap pihak BMT yang mengalami pailit karena tidak mampu mengembalikan nasa nasabahnya. Eks nasabah menjadi ragu, tidak yakin dan bahkan tidak memiliki kepercayaan menggunakan produk dan jasa BMT kembali setelah mengalami pailit. Eks nasabah lebih memilih menggunakan produk dan jasa keuangan lain yang lebih aman penggunaan produk dan jasanya dan lebih besar lembaganya seperti Bank bahkan terdapat nasabah yang tidak menggunakan lembaga keuangan untuk menyimpan uangnya tersebut.

Preferensi Eks Nasabah Ditinjau dari Tingkat Kepercayaan

Tabel.3 Preferensi Ditinjau dari Tingkat Kepercayaan

\begin{tabular}{lccc}
\hline & \multicolumn{3}{c}{ Chi Square } \\
\cline { 2 - 4 } Respon & Fo & Fh & $\frac{(\text { Fo-Fh })^{2}}{\text { Fh }}$ \\
\hline SS & 3 & 6 & 1,5 \\
S & 8 & 6 & 0,67 \\
KS & 5 & 6 & 0,16 \\
TS & 12 & 6 & 6 \\
STS & 2 & 6 & 2.6 \\
Total & 30 & & 10,39 \\
\hline
\end{tabular}

Berdasarkan hasil uji pada tabel 3, maka diperoleh perhitungan chi-square hitung sebesar 10,39 dengan df (degree of freedom $)=\mathrm{N}-\mathrm{k}$, dimana $\mathrm{N}$ merupakan data sampel dan k merupakan jumlah variabel dalam penelitian sehingga, $\mathrm{df}=30-4=26$ dengan taraf signifikansi sebesar $5 \%$ diperoleh chi-square tabel sebesar 38,885. Kemudian, diketahui bahwa chi-square hitung lebih kecil dari chi-square tabel yaitu $10,39<38,885$ maka, $\mathrm{H}_{0}$ diterima dan $\mathrm{H}_{1}$ ditolak, artinya dilihat dari tingkat kepercayaan eks nasabah BMT pailit tidak memiliki minat menabung terhadap BMT lain.

Berdasarkan wawancara yang dilakukan kepada responden yaitu eks nasabah BMT pailit di Kecamatan Ciawi pada awalnya nasabah memiliki tingkat kepercayaan yang tinggi dalam menggunakan produk dan jasa BMT, sehingga mempercayakan dananya untuk disimpan dan di kelola di BMT. BMT ini memiliki potensi jumlah simpanan yang besar karena nasabahnya lebih banyak berprofesi sebagai pedagang. Pendapatan yang diperoleh pedagang setiap harinya akan disimpan di BMT. Bahkan terdapat nasabah yang memiliki simpanan di Bank mengalihkan simpanannya dari Bank ke BMT dalam jumlah yang cukup besar karena menilai lebih mudah dan praktis.

Setelah BMT mengalami pailit, nasabah mengalami kerugian yang sangat besar. Berdasarkan keterangan narasumber, pihak BMT tidak memberikan informasi pengenai BMT yang mengalami pailit. Sehingga banyak nasabah yang tidak mengetahui mengenai hal tersebut, nasabah mengetahui BMT pailit dari rekan sesama pedagang atau dari orang di sekitar BMT yang sudah mengetahui bahwa BMT mengalami pailit. Dampaknya kejadian tersebut menimbulkan kekecewaan yang mendalam dari nasabah di BMT. Berdasarkan kejadian tersebut, tingkat kepercayaan nasabah terhadap BMT menurun bahkan nasabah tidak percaya lagi untuk menyimpan dananya di BMT. Hal tersebut mempengaruhi eks nasabah tidak 
memiliki minat menabung di BMT setelah BMT mengalami pailit.

\section{Preferensi Eks Nasabah Ditinjau dari Pengalaman}

Tabel.4 Preferensi Ditinjau dari Pengalaman

\begin{tabular}{lccc}
\hline & \multicolumn{3}{c}{ Chi Square } \\
\cline { 2 - 4 } Respon & Fo & Fh & $\frac{(\mathrm{Fo}-\mathrm{Fh})^{2}}{\text { Fh }}$ \\
\hline SS & 0 & 0 & 0 \\
S & 6 & 7,5 & 0,33 \\
KS & 1 & 7,5 & 5,63 \\
TS & 13 & 7,5 & 4,03 \\
STS & 10 & 7,5 & 0,83 \\
Total & 30 & & 10,82 \\
\hline
\end{tabular}

Berdasarkan hasil uji pada tabel diatas, maka diperoleh perhitungan chisquare hitung sebesar 10,82 dengan df (degree of freedom $)=\mathrm{N}-\mathrm{k}$, dimana $\mathrm{N}$ merupakan data sampel dan k merupakan jumlah variabel dalam penelitian sehingga, $\mathrm{df}=30-4=6$ dengan taraf signifikansi sebesar $5 \%$ diperoleh chi-square tabel sebesar 38,885. Kemudian, diketahui bahwa chi-square hitung lebih kecil dari chi-square tabel yaitu 10,82 <38,885 maka, $\mathrm{H}_{0}$ diterima dan $\mathrm{H}_{1}$ ditolak, artinya dilihat dari pengalaman eks nasabah BMT pailit tidak memiliki minat menabung terhadap BMT lain.

Berdasarkan wawancara dilakukan kepada responden yaitu eks nasabah BMT pailit, nasabah memiliki pengalaman yang kurang baik terhadap BMT pailit seperti sulit untuk meminta pengembalian dana kepada BMT, pihak yang akan dimintai pertanggung jawaban atas dana nasabah dan tidak ada pemberitahuan pailit oleh pihak BMT maupun dari petugas marketing nya. Selain itu, BMT juga berjanji akan mengembalikan dana nasabah ketika aset yang dimiliki BMT sudah terjual. Saat ini, aset yang tersisa di BMT yaitu gedung/ bangunan yang dihargai sekitar 5-6 milyar, nasabah berpendapat bahwa harga jual gedung/ bangunan tersebut dinilai terlalu mahal dan tidak akan menarik pembeli. Hal ini menyebabkan ketidakpastian kapan BMT akan melakukan pengembalian dana, sehingga nasabah tidak banyak berharap dan pasrah bahwa dananya tidak akan kembali.

Kemudian, tidak adanya pemberitahuan bahwa BMT tersebut mengalami pailit, nasabah mengetahui hal tersebut melalui nasabah lain yang mengetahui BMT pailit lebih dulu. Petugas marketing BMT juga tidak memberikan informasi kepada nasabah bahwa BMT mengalami pailit. Ketika nasabah bertanya kepada petugas marketing, petugas tersebut tidak memberikan jawaban secara jelas dan menimbulkan keraguan dalam diri nasabah. Hal tersebut menimbulkan pengalaman yang kurang baik dalam menggunakan produk dan jasa BMT, sehingga nasabah tidak memiliki minat menabung di BMT lain.

\section{KESIMPULAN DAN IMPLIKASI}

Berdasarkan hasil penelitian yang telah dilakukan, maka dapat disimpulkan bahwa:

1. Hasil analisis chi-square preferensi eks nasabah BMT pailit dilihat dari aspek syariah diperoleh nilai hitung lebih kecil dari nilai tabel sebesar 33,88 $<38,885$. Hal ini menunjukkan bahwa eks nasabah BMT pailit dilihat dari aspek syariah tidak memiliki minat menabung di BMT, walaupun eks nasabah meyakini BMT sesuai dengan syariat Islam.

2. Hasil analisis chi-square preferensi eks nasabah BMT pailit dilihat dari tingkat kepercayaan diperoleh nilai hitung lebih kecil dari pada nilai tabel sebesar 10,39 $>38,885$. Hal ini menunjukkan bahwa tingkat kepercayaan eks nasabah mengalami penurunan setelah BMT mengalami pailit, sehingga eks nasabah tidak memiliki minat menabung pada BMT.

3. Hasil analisis chi-square preferensi eks nasabah BMT pailit dilihat dari pengalaman diperoleh nilai hitung lebih kecil dari nilai tabel sebesar 10,82 < 28,885 . Hal ini menunjukkan bahwa eks nasabah mengalami pengalaman yang kurang baik ketika BMT mengalami 
pailit, sehingga eks nasabah tidak memiliki minat menabung pada BMT.

Terdapat beberapa implikasi pada penelitian ini, sebagai berikut:

1. Diharapkan dengan adanya penelitian ini mampu mendorong pemerintah dalam hal ini melalui Otoritas Jasa Keuangan (OJK) dan Kementrian Koperasi (Kemenkop) harus membuat aturan yang jelas dalam mencegah terjadinya BMT pailit di Indonesia. Salah satu cara yang dapat dilakukan melalui pendirian Lembaga Penjamin Simpanan (LPS) bagi Lembaga Keuangan Mikro Syariah (LKMS) salah satunya BMT yang merupakan lembaga mikro banyak digunakan oleh masyarakat. Sehingga, ketika BMT mengalami pailit, dana nasabah tetap aman meskipun hanya sebagian yang dijaminkan di LPS.

2. Hasil penelitian ini diharapkan dapat dijadikan acuan bagi LKMS dalam menjalankan kegiatan operasionalnya harus lebih transparan, jujur, dan amanah melakukan pengelolaan dana nasabah. Selain itu, BMT harus memperhatikan moral hazard dari pegawainya dan nasabahnya sehingga tidak menimbulkan kecurangankecurangan yang akan merugikan BMT. Selain itu, BMT harus lebih berhati-hati dalam memberikan pinjaman kepada nasabahnya. Keberadaan BMT seharusnya sangat bermanfaat terutama bagi masyarakat kecil menengah bukan malah merugikan nasabahnya jika BMT dikelola dengan baik.

\section{DAFTAR PUSTAKA}

Astarina, Giantari., dkk "Peran Kepercayaan Memediasi Pengaruh Kepercayaan Terhadap Niat menggunakan Kembali Jasa Go-Jek Di Kota Denpasar". E-Jurnal Manajemen Unud Vol. 6 (No.5), 2017. 2308-2334.

Dewi, A. S., \& Satria, A. D, "Perceived Of Religious
Pembentukan Preferensi Nasabah Bank Syariah". Jurnal Bisnis \& Manajemen Vol. 14 (No 2), 2014. 3550.

Guspul, A., \& Ahmad, A, "Kualitas Pelayanan, Kepuasan dan Kepercayaan Nasabah pada Koperasi Jasa Keuangan Syariah di Wonosobo". Jurnal PPKM III Vol. 2.

Kurniati, "Analisis Persepsi dan Preferensi Nasabah Muslim dan Non Muslim Terhadap Keputusan Memilih Perbankan Syariah di Provinsi DIY". Jurnal Ekonomi Syariah Indonesia Vol. 2 (No 2), 2012. 251-275.

Otoritas Jasa Keuangan, Statistik LKM

Indonesia Mei 2015. Diakses pada Mei 2018.

Schiffman, \& Kanuk. 2007. Perilaku Konsumen Edisi Kedua. Jakarta: Index Gramedia.

Suaidi. (2014). Upaya Pengembalian Dana Anggota Dalam Pailit di BMT Yogyakarta. Yogyakarta: UIN Sunan Kalijaga.

Sugiyono. 2010. Metode Penelitian Bisnis (Pendekatan Kuantitatif, Kualitatif. dan R\&D). Bandung: Alfabeta, CV.

Sugiyono. 2015. Metode Penelitian Kuantitatif Kualitatif dan R\&D. Bandung: Alfabeta.

Sukmana, A. A, "Penilaian Kesehatan KJKS BMT Binamas". Jurnal Akuntansi dan Keuangan Islam Vol. 2 (No 2), 2015. 125-144.

Sunyoto, D. (2013). Perilaku Konsumen (Panduan Riset Sederhana untuk Mengenali Konsumen). Jakarta: CAPS (Center of Academic Publishing Service).

Syawalia, M, "Preferensi Pedagang Pasar Tradisional Terhadap Sumber Modal". Jurnal Imliah Vol. 3 (No 1), 2015 